\title{
Chapter 7 \\ EU Policymaking and Research: Case Studies of the Communication on a Community Immigration Policy and the Common Basic Principles for Integration
}

\author{
Sandra Pratt
}

\subsection{Introduction}

Inter-governmental discussions on asylum and migration issues within the European Communities, as they then were, began in the 1980s in response to the growing concerns of several member states about migration to the EU and in particular the increasing numbers of asylum seekers reaching Europe. A special Task Force was later set up in the General Secretariat of the European Commission to facilitate these meetings. A particular issue was the number of third-country nationals crossing internal borders within the EU and then taking advantage of the different conditions contained in national legislation in order to apply for asylum - sometimes in more than one country - (so-called 'asylum shopping'). These concerns were heightened by the signing of the Schengen Agreement in 1985, designed to abolish internal border controls, which came into effect in 1995.

In the autumn of 1999, responding to new responsibilities conferred on the European Commission by the Amsterdam Treaty, which came into force in that year, a new Directorate General - for Justice and Home Affairs (DG JHA) was established. Included within it was a unit concerned with the development of immigration and asylum policy the core personnel of which had been previously working together on these issues within the Task Force. The Treaty of Amsterdam contained, for the first time, a skeleton legal framework for the development of a coordinated response to immigration and asylum and the protection of the external borders of the EU. It was therefore possible to provide a more comprehensive structure to carry out these tasks within the new DG.

The European Council held in Tampere in October that year agreed that a broad and comprehensive programme should be implemented. The Presidency

\footnotetext{
S. Pratt $(\varangle)$

Formerly Deputy Head, Immigration and Asylum Unit, Directorate General for Justice and Home Affairs, European Commission, Brussels, Belgium
} 
Conclusions of that meeting set out the so-called Tampere Milestones ${ }^{1}$ which provided not just for the coordination of national policies on admission and residence of third-country nationals but for the development of a Common EU asylum and migration policy including the following main elements:

- partnership with countries of origin

- a common European asylum system

- fair treatment of third-country nationals (with the aim of approximating their legal status to that of member states' nationals).

The Tampere milestones have remained at the heart of EU policy ever since and they were developed via a number of broad 5-year programmes called after the name of the city in which they were adopted (Tampere 1999-2004, The Hague 2004-2009, Stockholm 2009-2013). The objective was to increase cooperation both between member states and between the EU and third countries so as to regulate legal migration while also helping to reduce illegal flows. Over these years increasing priority was given to the prevention of illegal migration including the development of more robust controls at the EU's external borders and incentives to third countries to play a greater role in promoting the legal movement of their nationals and countering illegal movements.

As part of the common policy, the Amsterdam Treaty called for the harmonisation of existing legislation in certain key areas of asylum and, with respect to immigration, on the conditions of entry and stay of third-country nationals. However, the Tampere Council Conclusions opened the way for the development of a detailed programme designed to create a truly European approach to immigration and asylum. This would require creating a consensus amongst the then 15 and later 27 member states and finding sufficient common ground to move forward in an area where national sovereignty was strong, where the existing policies and legislation of member states were very diverse and where political priorities with respect to immigration and asylum varied, reflecting the different migration history and situation of each one.

The main drivers of policy from the European point of view were the fact that the movement of people was seen as an international phenomenon which responded to demand for immigrants for economic and social development within the Union but which needed to be managed more effectively. However, it was clear that, as internal border controls were removed, migration from outside the EU could certainly not be controlled by individual countries acting independently. It was recognised that the demand for labour was stronger in some countries than in others but the Commission believed that, because of changing economic and demographic factors, labour migration was likely, in a few years, to become a matter of concern to the EU as a whole. Although, at the time, movement of people between member states was low, it was thought that, with the development of the Single Market and closer financial and monetary union and as more countries joined Schengen, such

\footnotetext{
${ }^{1}$ Presidency Conclusions, Tampere European Council 15-16 October 1999 (SN200/99).
} 
movements were not only likely to increase but also to be increasingly necessary to ensure the economic development and competitiveness of the Union. In this respect third-country nationals might be particularly mobile. The key policy response was seen to be effective management strategies, which must be coordinated between the member states.

Consequently in the autumn of 1999 officials in DG JHA began the task of drafting detailed proposals for an EU immigration policy based on the general principles which had been agreed at the Tampere Council. These reflected a political consensus that had been developed over the previous two decades during the period of ad hoc intergovernmental activity but, as a new and substantial area of EU policy, one of the first tasks was to obtain more information about existing policies and practices at both national and international levels.

To do this a range of sources was tapped into: Commission papers from the earlier period, national reports from governments and other agencies and available research from national and international bodies. The research community in Europe played a particularly important role at this stage when the foundations of the common policy were being laid and the different ways in which this took place provide an interesting light on how the research-policy nexus operated during this period. This chapter will examine the complex relationships between migration research and policymaking at this time focusing on two of the key policy documents adopted in those early years, which are still fundamental to EU migration policy today - namely the Communication on a Community Immigration Policy, issued in November 2000, ${ }^{2}$ and the Common Basic Principles on Integration, adopted by the Justice and Home Affairs Council in November 2004. ${ }^{3}$

\subsection{The Communication on a Community Immigration Policy}

In 1999 there were already a number of EU sources on which to draw in the preparation of a common policy on migration. From the 1970s there existed Council resolutions concerning national legislation and the conditions in which migrant workers (both EU and third-country nationals) and their families lived in the member states. In the 1980s the Commission had published guidelines for a community migration policy ${ }^{4}$ specifying a number of areas where Community action could be most effective in managing migration. This had been followed by a Council Resolution in July $1985^{5}$ calling for greater exchange of information

\footnotetext{
${ }^{2} \mathrm{COM}(2000) 757$ final of 22 November 2000.

${ }^{3}$ Council Document 14615/04 of 19 November 2004.

${ }^{4} \mathrm{COM}(89) 48$ final of 1 March 1985 'Guidelines for a Community Policy on Migration'.

${ }^{5}$ Council Resolution of 16 July 1985 concerning guidelines for a Community policy on migration (85/C186/04).
} 
amongst member states about the numbers and conditions in which third-country nationals were received in their respective countries. Then in 1991 a Commission Communication argued that a common response was needed to deal adequately with immigration. ${ }^{6}$ In 1994 a more comprehensive Communication had been published on migration flows and ways in which greater cooperation between the member states could enhance the overall management of migration movements in Europe. ${ }^{7}$ Finally in December 1998 the 'Vienna Action Plan' had been adopted by the European Council setting out priorities, including asylum and immigration, for the area of freedom, security and justice, which was to be established the following year by the Amsterdam Treaty. ${ }^{8}$

However, having in 1999 for the first time a legal basis for taking concrete and enforceable measures and setting priorities, it was important to find out as much as possible about national policies in the field at the beginning of the twentyfirst century, to see what was common to more than one member state, where the major differences lay and the contexts in which these policies operated. At the time the 15 member states could be divided into broad categories depending on their experience of migration. There were those with a long history of immigration (and often of emigration as well) such as France, Belgium, Germany, Luxembourg, The Netherlands and the UK. Others had experience mainly of emigration of their nationals - notably the southern countries Italy, Spain, Portugal, Greece and also Ireland - a situation which was soon to change. Some had little recent experience of either kind of movement - particularly in northern Europe, notably the Scandinavian countries. The New member states who joined the Union in and after 2004 mostly fell into this latter category.

For European Commission officials to obtain detailed information about the migration policy of the member states was not always easy since much was contained in legal texts in the national language and if more general policy documents were available they were also mostly in the national language. Information could always be requested from senior officials in national administrations via questionnaires and relevant statistics could be collected but this was time-consuming for all concerned and was not a very realistic option given that about 6 months were available for the preparation of the Communication including the consultation procedure within the Commission and the time needed for translation.

Some very valuable comparative information was, of course, available from international sources, notably the Organisation for Economic Cooperation and Development (OECD), the United Nations (UN) and the International Organisation for Migration (IOM). Since the establishment in 1985 of the IGC (the InterGovernmental Committee on international migration) there had also been an exchange of information amongst a number of European countries, the USA, Australia, Canada and New Zealand. The European Commission participated in

\footnotetext{
${ }^{6} \mathrm{SEC}(1991) 1855$.

${ }^{7} \mathrm{COM}(94) 23$ of 23 February 1994 on immigration and asylum policies.

${ }^{8}$ Presidency Conclusions of the Vienna European Council 11-12 December 1998.
} 
these discussions. Comparable statistics, however, were extremely difficult to obtain and it was not until the adoption of a Regulation in 2007 that common definitions and standard topics were agreed by member states for the provision of data to Eurostat, the statistical office of the European Union. ${ }^{9}$

A very important information avenue at that time was, therefore, that of academic research. In this first phase the Commission developed an active policy of seeking out research which would provide reliable evidence on which to base detailed policy. Research findings were especially useful when they were objective and included comparative analysis of the impact of national policy both in the EU and in other parts of the world. However, in the early 2000s there was very limited comparative information available and certainly very little which gave an overview of all or even a number of the then fifteen member states. Relevant research was often difficult to access. Bibliographical searches took time - search tools were not as advanced then as they are now - and in particular it was difficult to quickly unearth what was relevant to policymaking from research results, which were often very detailed and limited in scope.

At the same time research carried out under the EU Research Framework Programmes largely covered immigration from a socio-economic point of view since these were the areas of most interest for EU policy at the time, particularly for DG Employment and Social Affairs. It should be remembered that the topics for the Calls for Proposals made within these programmes were decided in general terms by the Commission to reflect the needs of the different DGs, but there was then an open competition for the allocation of resources and specific proposals within the general guidelines were made by those applying. There was, therefore, scope for researchers to develop their own ideas within the overall strands. It was only with the Amsterdam Treaty that it was possible for the Commission to include a wider range of issues and to promote the development of comparative study in broader research programmes on different aspects of immigration and asylum. Such research has since become a very valuable source of information to inform policymaking with procedures in place to evaluate results and to bring policymakers and academics together in seminars and conferences to examine the results. ${ }^{10}$

After 1999 other sources of funding were also available to DG JHA to commission more focused research with shorter deadlines and precise specifications arising from specific and immediate policy needs. These were open to the research community, usually via restricted tender proceedings, and were invaluable methods of obtaining information to inform some of the early legislative and policy proposals. The drafting of most of the initial migration and asylum legislation, for example the

\footnotetext{
${ }^{9}$ Regulation (EC) No 862/2007 of the European Parliament and of the Council of 11 July 2007 on Community statistics on migration and international protection and repealing Council Regulation (EEC) No. 311/76 on the compilation of statistics on foreign workers.

${ }^{10}$ For an overview of 34 large-scale projects related to migration/integration funded by DG Research through its FP6 and FP7 programme, see Ann Singleton, Moving Europe: EU research on migration and policy needs, European Commission, DG for Research, EUR 23859 EN.
} 
EU directives on family reunification and those on asylum, benefited from analyses resulting from a specific research contract, usually including a comparative survey of existing national legislation. Commissioned research was also an important element in the early work on the formulation of integration policy. There were studies for example on the use of benchmarking to evaluate integration policies and practices and feasibility studies such as on the possibility of setting up a European Migration Observatory.

However, because time was short, a more direct approach was taken with respect to the 2000 Communication, through consultations with the research community on a formal and informal basis, as individuals and via the establishment of expert groups. Contacts were made through colleagues in the Commission and via senior civil servants, members of relevant Council committees, who advised on their national experts. A selection of immigration specialists from across Europe, including input from researchers from North America and elsewhere, was brought together on a number of occasions to discuss preliminary ideas and to advise on the different policy options which were under consideration within the Commission at the drafting stage. A particularly important seminar took place at the Luso-American Foundation in Lisbon in the spring of that year where some of the early ideas were analysed and discussed with a number of leading researchers. At the same time European Commission officials participated themselves in academic conferences to pick up information and to make contacts in the academic world across the member states.

The history of this Communication also illustrates a very important element of immigration policymaking and that is the influence of research from outside Europe, which had a major impact on the drafting of the publication. Early in 2000, the UN published demographic forecasts of changes expected in the world's population in the twenty-first century. These highlighted for Europe a dramatic decline in population in the EU, a significant increase in people over 65 and a decrease of those of working age. They were extrapolations based on different scenarios concerning death rates, birth rates and immigration but they showed that whether one took the high, medium or low possibilities, significant changes were to be expected and the report, published in March, suggested that migration could be one of the ways to deal with declining and ageing populations. ${ }^{11}$ The press seized on the results when the report was first published - and they created considerable interest all over the world, but particularly in the EU. The significance of immigration, the need for immigrant workers to take up the jobs created by a shrinking work-force, coming at a time when job shortages were beginning to be felt in a number of countries - notably in the much publicised, although it turned out also exaggerated, IT industry - caught both politicians' and the general public's attention.

\footnotetext{
${ }^{11}$ United Nations, Replacement Migration: is it a Solution to Declining and Ageing Populations? Population Division, Department of Economic and Social Affairs, United Nations Secretariat, 21 March 2000 (ESA/WP.160).
} 
This created an opportunity to abandon the cautious position taken in the early drafts of the 2000 Communication, of migrant flows and how they might impact on EU policy, and to take a much more pro-active position stressing the need for economic migration and consequently for management at the European level. The climate created, in terms of the acceptance of the economic value of immigration by business leaders and by the media and their impact on public opinion, has never been so propitious. In this context the emphasis in the new draft could be placed on identifying best practice and on taking an objective and long-term view of the kind of policy that would best meet the future economic and social needs of the EU. As outlined above, the role of the research community in this endeavour was considerable.

The Communication was adopted without major comment from the member states and it was also given a favourable reception by both the European Parliament and the Economic and Social Committee to which it was referred for an opinion. It was, of course, only a document setting out and giving justification for the proposed common policy and it contained no specific issues on which decisions had to be taken. However it created the framework for the EU approach to immigration, which has served as the basis for the wide-ranging policy we see today. It was a founding document for a new policy field and the Commission and policymakers had drawn extensively on the research community. The influence of the latter was probably greater then than it has been ever since.

There was less influence from other policy areas within the Commission and from national governments since the likely impact of migration and of the policy options that had been put forward were perhaps not fully appreciated at the time. The period of grace was not to last long as discussions about how far migration issues should be mainstreamed into other policy areas at national and European level and to what extent and for how long they should have a special status became more important. The impact of migration policy first on employment and then on external affairs and trade was quickly recognised by the relevant DGs. Issues of national sovereignty became stronger as national officials became more involved in the decision-making process at the EU level.

The proposals subsequently put forward for a coordination procedure for member states' migration policies were not accepted and the drafts for specific directives concerning the approximation of the legal status of immigrants were either withdrawn (as was the case for the directive on the admission of labour migrants) or adopted after long months of discussion and amendment by the Council. The publication of the Süssmuth report in Germany in $2001^{12}$ and the subsequent constitutional challenge of the proposed policy options put forward by the German government had the effect of slowing down on-going discussions in the Council. This was particularly important with respect to the directive on the admission of labour migrants - an extremely sensitive issue for many member states in spite of

\footnotetext{
${ }^{12}$ ICM - Independent Commission on Migration to Germany (2001) Structuring Immigration, Fostering Integration, Report by the Independent Commission on Migration to Germany, Berlin.
} 
the fact that the Commission's proposals concerned only the status of those who might be admitted but had no impact on the number to be selected which was to remain a decision taken by the member state concerned. The absence of a common position on labour migration to the EU is still today a major defect of the common policy. With the accession of the New member states in 2004 and the rapid growth of mobility within the EU, public opinion hardened against migration, the subject shot up the political sensitivity agenda and has remained there ever since, making progress with the development of EU policy on migration ever more difficult.

The slightly laissez-faire days of the early 2000s together with the very close links between policy and research are now in the past. However, the overall blueprint which was accepted then has remained in place as the basis of EU policy even though subsequently it has been influenced in tone and in direction by an increasingly negative public opinion and in recent years by rising unemployment in Europe and the financial and economic difficulties resulting from the banking crisis of 2008.

\subsection{The Common Basic Principles for Integration}

The development of a common approach to integration policy during the period 2002-2007 illustrates other ways in which the research-policy nexus operated in an area where there was no legal basis at that time for the Commission to propose legislation (see also Chap. 16 on the EU). However the need for greater cooperation and exchange of information about the way integration took place in the member states was becoming more evident. As a result in 2002 the Justice and Home Affairs Council decided to establish National Contact Points on integration and in 2003 the European Council invited the Commission to present annual reports on migration and integration in the EU.

The National Contact Points were senior officials from the member states chaired by the Commission who met two or three times a year on an informal basis (and were therefore not part of the formal Comitology structure that assisted the European Commission in policymaking). They played a very important role in the exchange of information and good practice and particularly in the development of ideas for policy on integration. Because of their informal nature, they were able to interact directly with the research community. Results of interesting research were presented by the researchers concerned at meetings of the National Contact Points, the project to establish a series of handbooks of good integration practice brought the members of the committee together with researchers and practitioners from civil society in a series of technical workshops and contributed enormously to the exchange of information, the sharing of ideas and of research results. Many members of this group were also actively involved at national level in the preparation of the ministerial meetings that developed national integration agendas. The flow of information between member states developed substantially involving exchanges not only between senior officials and researchers, but also with civil society and others involved in integration programmes. This took place not only at European 
level but there was a spin-off effect at national level too. As interest spread on the effectiveness of national models of integration the national research community became more involved with decision makers as these programmes were reviewed and compared at national level. The establishment in 2003 of a fund to finance pilot projects and preparatory actions in the field of integration (known as the INTI Fund), which was the precursor of the EU Integration Fund, had an important impact on these exchanges.

Meanwhile, the Commission had published a Communication in 2003 on immigration, integration and employment ${ }^{13}$ setting out proposals for the development of vigorous integration policies for third-country nationals as a response to the mandate given in the Tampere conclusions. The preparation for this document had also included a meeting of researchers, politicians and others called by the Commission and held in Florence in the spring of that year. A number of interesting ideas were born at that meeting including the notion of civic citizenship, which played an important role in subsequent discussions of the nature of citizenship for third-country nationals resident in the EU. This Communication, which was prepared in cooperation with DG Employment and Social Affairs, emphasised both the importance of the role of migrants in meeting the Lisbon employment goals, and that the economic and social benefits of migration could only be realised through successful integration. It also introduced arguments for mainstreaming integration within the framework of a number of existing policies and programmes at EU level.

The Communication was scheduled for discussion at the European Council to be held in Thessaloniki under the Greek Presidency in June 2003. As a preparation for this Council the research community took part in what might have been seen as a surprising new initiative by the Presidency, but one which subsequently played an important role in policymaking at the European level and in the preparation of the Common Basic Principles: the Athens Migration Policy Initiative (AMPI). The instigator was an American with Greek origins, Demetrios Papademetriou, director of a leading migration think-tank in Washington - The Migration Policy Institute (MPI). He had close connections with members of the Greek government at that time and persuaded them to prepare for the discussions at the Council via a seminar of senior officials with input from the research community. He was able to draw on European expertise, readily accessible through the International Metropolis network, to bring researchers from Europe and North America to work with European policymakers. The issues were new at the EU Council table in the early 2000s and there was a need to develop and inform the process of information exchange and consensus building among the senior national civil servants who participated in the decision-making process, together with the officials of the Commission and the Council Secretariat. The researchers concerned saw and seized an opportunity that had far-reaching impacts on the formulation of policy. ${ }^{14}$

\footnotetext{
${ }^{13} \mathrm{COM}(2003) 336$ final of 3 June 2003.

${ }^{14}$ The Athens Migration Policy Initiative (AMPI) started in 2002-2003 and continued providing support to a number of successive presidencies at a time when some significant landmarks were reached in the development of European policy. The method was the same - the organisation of informal workshops or seminars for senior civil servants to discuss the issues and possible options,
} 
However, the Thessaloniki Council did not attempt to develop a common definition of what integration might mean in the EU context since there was no legal basis (until the Lisbon Treaty in 2007) for doing so. In fact the Commission did not then, or now, feel that it would be helpful, given the very different situations in the member states concerning migration and integration, to propose a specific model for integration in Europe. However, it was felt that there was a need for a more detailed interpretation of what integration in the EU might mean. This was in a context where measures harmonising the conditions of residence of legal migrants were coming into force as part of EU Directives on the admission of different categories of immigrant, notably those coming in as family members ${ }^{15}$ and those qualifying after 5 years for long-term residence status. ${ }^{16}$ The coming into force in 2003 of EU employment and racial equality legislation ${ }^{17}$ was also having an impact, particularly noticeable since many member states had not previously had national legislation of this kind. Political attention was being drawn to the issues arising from the growing social diversity in many countries and this in turn influenced thinking about policy developments in the area of integration. There was a perceived need to clarify the principles and practice of integration and to provide a framework to assist member states developing policies at national level.

As a result in July 2004 at the beginning of its Presidency, the Dutch announced in the Council at a meeting of the SCIFA (Strategic Committee on Immigration, Frontiers and Asylum) their intention to develop common basic principles to form the basis of this framework. The Dutch Ministry of Justice immediately prepared a draft on which they consulted with MPI in Washington, with whom they were also working on the preparation of a seminar of senior officials in the member states and leading researchers to be held in Amsterdam in the autumn. In its turn, MPI used its AMPI network to mobilise European integration specialists, in particular researchers in The Netherlands, and involved them in the drafting of a series of statements which contained principles, guidelines and some priority topics which could form the basis of each member state's integration policy. As a result of these exchanges between researchers, MPI and Dutch Ministry officials, the principles were focused on key areas and common problems rather than on national practices. That made them in the end acceptable to all member states, the

based on papers prepared with the active assistance of researchers. This led to the development of a level of consensus which could be built into the preparation of the Council conclusions which announced the new policy including support for the preparation by the German Presidency of the Potsdam conference of integration ministers in 2007 which set the agenda for integration policy for the next few years.

${ }^{15}$ Council Directive 2003/86/EC of 22 September 2003 on the right to family reunification.

${ }^{16}$ Council Directive 2003/109/EC of 25 November 2003 concerning the status of third-country nationals who are long-term residents.

${ }^{17}$ Council Directive 2000/78/EC of 27 November 2000 establishing a general framework for equal treatment in employment and occupation and Council Directive 2000/43/EC of 29 June 2000 implementing the principle of equal treatment between persons irrespective of racial or ethnic origin. 
Netherlands included. The Dutch Ministry of Justice held a series of discussions on the draft document during the autumn with member states and the Commission, leading to the adoption of the Common Basic Principles (CBPs) by the JHA Council in November $2004 .{ }^{18}$ It is interesting to note, however, that the draft presented to the meeting of SCIFA in September 2004, largely put together by AMPI and Dutch researchers, did not change substantially from the version finally adopted by the Council.

While they had no binding legal status on the member states the CBPs have nevertheless made an important contribution to the thinking about national integration policies in a number of countries, notably in Spain and Ireland and some of the new member states. Implementation of the CBPs was promoted through the European Integration Fund and they remain a point of reference at EU level - an interesting example of how European policy can take a very different path from national policy.

\subsection{Conclusions}

What do these examples illustrate about the research-policy nexus in the context of the early development of common European immigration and integration policies?

Firstly, there was a very strong input of researchers to European policymaking. Since there was not at first great interest from other policy areas in the Commission nor from national governments, there was an opportunity in those early years of the new millennium for researchers not only to influence policy indirectly through their research publications, but also directly. This took place through contributions individuals made in seminars held by the Commission and other institutions to discuss ideas for policy options, but also by their impact on policymaking via their contributions to the preparation of documents such as the drafts of the Common Basic Principles. The research-policy nexus that developed at this period also had an impact on the development of this nexus at national level both in terms of procedures (relationships with the research community) their closer involvement in policymaking and with respect to content. This was particularly so since many countries, for example Sweden, Spain, Germany, Ireland, and the Netherlands, were either undertaking fundamental re-thinking of their integration policies or developing such policies for the first time.

The influence of (members of) the research community was in part the consequence of the vision of the Commissioner for Justice and Home Affairs, Antonio Vitorino, and of his officials, to fulfil the Tampere mandate by proposing for the long term a policy which was as objective as possible and based on the best practice and experience available in Europe. In doing so they were greatly helped by the fact that in such a new policy area they could mobilise and finance a variety of sources and

\footnotetext{
${ }^{18}$ Immigrant Integration Policy in the European Union, Annex to the JHA Council Conclusions of 19 November 2004.
} 
procedures as described above. The progressive development of relatively open new research opportunities under the Fifth, Sixth and Seventh Framework Programmes by DG Research, and the increase of more targeted research by DG JHA and DG Employment and Social Affairs, provided a wide range of possibilities for the research community to influence policymaking in these areas albeit less directly than in the early years this chapter has been discussing.

A further significant factor was that public opinion towards immigration, which always had and still has a major impact on politicians and policymakers in this area was, at that time, mainly neutral or even positive, reinforced by the new information available about the demographic changes taking place in Europe and a favourable economic situation. This is illustrated by the rewriting of the early version of the 2000 Communication to take a more positive view of migration as a factor in EU development. That early episode contrasts starkly with the subsequent period in which the making of European legislation on immigration and asylum became much more problematic in the difficult process of trying to reconcile very diverse national viewpoints in an environment that became ever more hostile to immigration. New proposals were invariably much watered down, after long months of negotiations in the Council decision-making process, and later also in the co-decision procedure with the European Parliament.

It is important to note that the nature of the research-policy nexus at European level was complex; a complexity that was not only due to the constantly changing political context but also to the fact that so many different interests (and interest groups) were involved in European policymaking. These included different interests in the Council (representing the member states) and the Commission on the one hand; within the Comitology structure of the EU itself, the advisory role of institutions such as the Committee of the Regions, the European Economic and Social Committee - which was particularly influential with respect to integration and the European Parliament, especially when reinforced through the co-decision procedure but at that time still in an advisory role. Within the EU, DG JHA played a leading role in consulting the research community. There were, however, numerous other external agents with specific interests such as employers' organisations and trade unions, human rights groups and migrants' rights NGOs, all of whom had access to Commission officials who welcomed their views. Many of these interest groups also mobilised research for their own purposes.

In the context of such complexity, the content and form of the information that was exchanged between policymakers and researchers was very varied. It was not only through publications, the traditional way in which research findings are made available to policymakers, that influence was exercised. Since 2002 there has been a gradual rise in the preparation of policy papers and policy briefs, short extracts and other documents drawing the attention of policymakers to research findings and to new ideas. The Commission itself developed procedures to plan and highlight results of research carried out under successive Research Framework Programmes as they increasingly included research in the field of immigration from FP5 onwards. Through these programmes, the Commission made a significant contribution to the development of a European research community by supporting comparative 
research and fostering the establishment of research networks such as the IMISCOE Network of Excellence (2004-2010). The Commission (DG JHA) also set up its own research facility to promote cooperation between member states (the European Migration Network), and, in consultation with the research community, started on the long road to improving the collection of basic and comparable statistics.

Finally, it can be seen from these examples that without compromising choice of subject or scientific rigour, the relationship between the research community and policymakers can work well when a fairly regular interaction develops between them on the basis of a common agenda. This requires on the part of the researchers a thorough understanding of the way in which decisions are being taken, and the time and form in which to present research results that are relevant, and usable. The Athens Migration Policy Initiative shows what can be achieved. The policymaking context at that time was particularly favourable but it is nevertheless quite remarkable how the research community in Europe was mobilised over a period of several years in the early 2000s to provide such a degree of input and influence to European migration and integration policy.

Open Access This chapter is distributed under the terms of the Creative Commons Attribution Noncommercial License, which permits any noncommercial use, distribution, and reproduction in any medium, provided the original author(s) and source are credited. 